\title{
CONCEPTUAL METAPHOR AS MEANS OF TEACHING ENGLISH SPEECH PATTERNS IN HIGHER EDUCATION
}

\author{
Svetlana Matsevich \\ Pskov State University, Russian Federation \\ Irina Korenetskaya \\ Pskov State University, Russian Federation \\ Anna Kuzmichenko \\ Pskov State University, Russian Federation
}

\begin{abstract}
The article focuses on the relevant problem of finding new methods in theory and practice of teaching foreign languages and attempts an interdisciplinary research of conceptual metaphors both as a phenomenon of linguistics and English-language training. The authors view the research novelty in considering conceptual metaphors of educational discourse as one of the means of teaching students English speech patterns. The research aim is to identify basic conceptual metaphors of educational discourse and describe the algorithm of using them in teaching English at universities. The primary methods of the study are conceptual-taxonomic analysis and the Metaphor Identification Procedure (MIP). The materials of the study include the articles of the English-language educational discourse and topical lectures on Education, Communication, Science and Society at TED Talks platform. The main research results present conceptual metaphor classification and its possible use as the means of teaching English speech patterns. The basic mechanism of learning new English speech patterns through conceptual metaphors suggests the implementation of cognitive-communicative approach. The results of the research are addressed to master and post-graduate students when learning English in professional sphere of education sciences.
\end{abstract}

Keywords: cognitive-communicative approach; conceptual metaphor; conceptual-taxonomic analysis; educational discourse; English-language training; higher education; speech pattern.

\section{Introduction}

The problem of finding new teaching methods seems rather relevant in theory and practice of teaching foreign languages nowadays. The combination of linguistics and teaching theory may offer some fresh solutions to the problem. Conceptual metaphor theory seems particularly productive in this regard, as cognitive structures are implemented in speech, including both native and any foreign language. 
When learning English in the professional sphere of pedagogics master and postgraduate students are faced with scientific texts about education. These texts are texts of a scientific style and collectively educational discourse.

The combination "scientific discourse" becomes as natural as "scientific text". The language of science is beginning to be seen as a verbalization of continuous scientific thinking. Scientific discourse is interpreted as phenomenon that reflects basic parameters of epistemological activity.

The change in the philosophical paradigm, expressed in the formation of the concept of new rationality, entailed the study of discourse, traditionally associated with rational thinking sphere. Scientific discourse is a unity of the rules of communicative behavior and text formation as a result of communication in the social sphere and discursive picture of the world creation.

As integral communicative-cognitive space, scientific discourse is modeled through the use of various linguo-cognitive models correlated with the stages of mental activity. Such a means of scientific knowledge as metaphor acquires the role of cognitive model in scientific discourse and becomes a figurative form of rationality.

Many scholars write that metaphor is one of central figures in human cognition as a whole, when a certain phenomenon is perceived by analogy with the already known one and receives linguistic description similar to that used to name already known facts and phenomena.

Metaphor permeates human thinking and, therefore, language. Playing an important role in language as a whole, it inevitably is essential for the process of scientific description of phenomena and objects of reality. Thus, scientific educational discourse also contains a large number of metaphors that are designed to improve the process of description and, therefore, perception of this description by readers and listeners.

The present research, conducted in the course of cognitive-communicative approach, offers to consider the basic approaches of teaching new English speech patterns through conceptual metaphors.

\section{Literature review}

Metaphor studies have been conducted since the epoch of Aristotle, who was the first to introduce the idea that metaphor is not only the element of speech but also the element of mind. Though then the idea had been dropped for centuries, and Aristotle's successors paid their attention to metaphor as a unit of rhetoric solely, it nevertheless finally found its embodiment in the works of G. Lakoff and M. Johnson, especially in their research "Metaphors We Live By" (Lakoff \& Johnson, 1980). 
The researchers introduced the idea so fundamental yet so simple: metaphors are everywhere around us - they rule our lives and form our minds. The basis of conceptual metaphors underlies in the "embodied" experience of human cognition, i.e. on how the human brain and body function in interaction with the surrounding world. According to the theory, this "embodiment" happens as the transference of meaning from one sphere ("source-domain"), which is usually tangible, to another sphere ("target-domain"), which is usually abstract. Thus, the essence of metaphorization is the transfer from the "source-domain" to the "target-domain" of those cognitive structures in terms of which the experience related to the "source-domain" was structured (Lakoff \& Johnson, 1980).

Simultaneously with the advancing in metaphor research, the concept of "educational discourse" came into scientific circulation, when researchers reached the conclusion that style is not only a socially realized and functionally determined internally combined set of techniques for the use, selection and combination of verbal communication means in a particular language (Vinogradov, 1981) and the main thing in the scientific text is not the simple use of "selected language means", but a special type of communication and thinking (Kozhina, 1993).

Conceptual metaphor research can be centered on both written texts (articles, documents, etc.), and oral lectures, that have exercised increasing attention in the field of discourse analysis and applied linguistics. In educational discourse in general and teaching English speech patterns in particular, metaphor is used to organize the content of theory-building, to instruct, and persuade the students (Gibbs, 1994), as well as description, explanation, exemplification, clarification, summation, restatement, and evaluation, agenda management (Cameron \& Deignan, 2006), transferring signals about the organization of the lecture (e.g., key points, supporting statements, examples, summaries, etc.).

\section{Methodology}

The research is formally divided into two stages:

1. Identifying conceptual metaphors in educational discourse;

2. Describing the algorithm of using conceptual metaphors in the process of teaching English speech patterns to graduate and postgraduate students in the professional sphere of pedagogics.

\section{Stage 1. Identifying conceptual metaphors in educational discourse.}

As our research aims at covering as many cases of using a conceptual metaphor in educational discourse as possible, we have made an attempt to analyze various kinds of materials including both traditional articles on education and TED lectures. 
To identify conceptual metaphors in educational discourse we use two basic methods: conceptual-taxonomic analysis (written texts) and the Metaphor Identification Procedure (TED lectures).

Conceptual-taxonomic analysis as a means of identifying metaphors allows us to identify the main metaphorical patterns of thinking about education at different stages of the educational development (education sciences) and to trace their evolution. It allows us to penetrate into the laws of discursive (non-linear) deployment of the text, to reveal the internal relationship among global metaphorical concepts, terminology systems and concepts.

The material under analysis is represented by scientific works on education written by English native speakers (Altman, 1996; Broughton, 2003).

Traditional written texts can be enriched with an on-line version of lecture delivering at TED Talks platform with easy access to any urgent current issue, but metaphorical nature of language makes it complicated for non-native speakers to understand them. The analysis indicates that TED Talks are rich in metaphoric lexical units. That is why TED Talks platform is a broad area for metaphor identification and interpretation.

High metaphoric density in TED lectures and the need to interpret them may suggest that the teaching of metaphor should be integrated into teaching English speech patterns in Higher Education. In addition, even if metaphor is not as frequent, its existence may still cause difficulties in interpreting metaphors and lead to wrong conceptualizations of the lecturer's key points (Littlemore et al., 2011).

By means of the methodology of identification and quantification we can examine the use of metaphor in TED Talks, its density and basic conceptual models within lectures in the area of social sciences and education.

The data of the current research comes from the website of TED Talks (the list of talks is given in the Reference List). The lectures were chosen from the point of view of their practical application within the framework of English as a foreign language teaching, where we refer to a number of different issues: Education, Communication, Science and Society. The talks under study were selected from the list of most frequently viewed talks (with a minimum of 500,000 view counts) in the areas, mentioned above. After compiling a list of popular talks in this particular discipline, the lectures were selected to include only those where the presenters were native speakers of English, and with duration of about 20 minutes. At the end, 2 talks in 4 spheres were selected for the corpora of this study. All in all, 8 talks have been analyzed.

The following steps were taken to complete the analysis with the Metaphor Identification Procedure (MIP) developed by the Pragglejaz Group (2007):

1) Pattern recognition by listening to the talks and consulting the transcript; 
2) Identifying lexical units;

3) Identifying metaphors;

4) Taking into account intercoder reliability (comparing the content of the metaphor unit in the original and target language) as metaphor is not just the detection of pattern but a creation of a new one.

Stage 2. Describing the algorithm of using conceptual metaphors in the process of teaching English speech patterns to graduate and postgraduate students in the professional sphere of pedagogics.

The basic mechanism of learning new English speech patterns through conceptual metaphors suggests the implementation of cognitive-communicative approach.

Graduate and postgraduate students working with educational discourse face two main objectives: to understand a foreign educational text and to produce scientific educational texts in the form of presentations, reports, posters, abstracts and articles in the language under study.

The process of metaphorization is characteristic of the terminology of educational discourse in the same way as for other branches of scientific knowledge. Cognitive metaphorization proceeds in comparison of the object metaphors to the signs, properties and actions characteristic of other classes of objects (Telija, 1988). This creates the meaning that is constantly inherent in the metaphor object, e.g. brilliant education, deep knowledge, highly educated person.

Cognitive metaphor is one of the keys to readers' understanding of a particular text, i.e. of the content that the author of the text puts into it, expecting an adequate understanding of the information that he puts from the readers.

The research of cognitive metaphors in scientific speech, however, cannot be limited to a simple statement of the presence of metaphors in the scientific functional style.

Scientific speech in itself is not a homogeneous phenomenon. This is reflected in various kinds of genres of scientific texts, depending on their volume, orientation, conditions of creation, oral or written nature, etc. There is a need to trace the extent to which cognitive metaphors are realized in each of the varieties of scientific educational discourse. Moreover, cognitive metaphors can either be regularly reproduced in speech or have individual author's features.

Since educational activity is a kind of sociocultural practice, the complex of unique educational objects with all the variety of their links as a result of activitytargeted localization in the sociocultural space can form a specific educational cluster of concepts, which we observe in educational discourse.

Such clusters (the term is offered by Lodatko, 2013) can be formed on various grounds depending on the tasks to be solved. It requires localization of certain educational objects, the selection of which is carried out in accordance 
with the established criteria, based on rationality and methodological approaches to solving the emerging problems.

In the field of education we can distinguish such clusters, for example, as: pupil, student; teacher, lecturer, professor; schools and other educational institutions; educational resources and facilities; technologies and teaching methods, etc.

The cognitive metaphor as a tool oriented towards the reinforcement of semantic universals of each model specification, together with the totality of its characteristics and cultural-specific connections inherent in a particular educational cluster, makes it possible to single out, in the educational discourse under analysis "student” cluster for example, such basic cognitive components as: student as an object, student as a recipient, student as consumer, student as a wanderer, student as a traveler, student as a climber, student as a subject, student as a builder, student as a constructor, student as a designer, student as a player, etc. A teacher is a trainer, philanthropist, benefactor, source of knowledge (container), assistant, gardener, servant, companion enemy, etc.

Each cognitive metaphor does not only expand the idea of a certain educational object, but also stimulates a variety of ways and styles of thinking about it in terms of metaphorical image which being a mental unit forms a stable idea of a simulated phenomenon in the aggregate of its connections and manifestations through possible specific models.

Metaphorical images that arise in the imagination of a student and accompanying his activity in the process of operating cognitive metaphors, due to their mental nature, are characterized by subjective diversity. This creates prerequisites for the development of author's metaphors.

Understanding the essence of cognitive metaphor by a graduate (postgraduate) student opens the way to improving his conceptual and semantic base and instrumental support for perception of educational discourse and production of his own educational texts in a foreign language using universal cognitive metaphors that provide both epistemological activity and scientific creativity.

The use of cognitive paradigm in studying foundations of human thinking and creativity in educational discourse makes us take a fresh look at the role of language communication in the human cognitive sphere formation in the field of cognition, education in particular.

\section{Research results}

Stage 1. We would like to demonstrate the implementation of our approach on the example of EDUCATION concept.

Having analyzed the corpora, we can distinguish the basic cognitive components in the concept of EDUCATION which is presented in scientific 
SOCIETY. INTEGRATION. EDUCATION

Proceedings of the International Scientific Conference. Volume V, May $22^{\text {th }}-23^{\text {th }}, 2020.494-504$

educational discourse as: a living being, physical object, process, business, growth / evolution, journey, game, building / structure, product, wealth / value. We have chosen associations with EDUCATION based on the frequency principle.

Below we present the table, created by the authors in accordance with the method of conceptual-taxonomic analysis and containing examples from the corpora (Table 1).

Table 1 Cognitive models of EDUCATION concept

\begin{tabular}{|c|c|c|}
\hline \begin{tabular}{|c|}
$\begin{array}{c}\text { Cognitive } \\
\text { component }\end{array}$ \\
\end{tabular} & $\begin{array}{l}\text { Conceptual } \\
\text { metaphor }\end{array}$ & Example \\
\hline Living being & $\begin{array}{l}\text { EDUCATION } \\
\text { IS A LIVING } \\
\text { BEING } \\
\end{array}$ & $\begin{array}{l}\text { Higher education... was called on to offer professional training. } \\
\text { Should not our educational system directly address these issues? } \\
\text { We reshape our educational activities to meet the emerging needs... }\end{array}$ \\
\hline $\begin{array}{l}\text { Physical } \\
\text { object }\end{array}$ & $\begin{array}{l}\text { EDUCATION } \\
\text { IS A } \\
\text { PHYSICAL } \\
\text { OBJECT }\end{array}$ & $\begin{array}{l}\text { You're on a roll. You got two right. } \\
\text {...model of higher education...is out of synchrony with the needs of } \\
\text { the times. } \\
\text { We hold high the banner of academic freedom. } \\
\text { Students receive... a broad liberal education. } \\
\text {...higher education exploded with a whole new set of } \\
\text { responsibilities. } \\
\text {...state governments poured money into higher education... } \\
\text { Foundational knowledge ....should continue to be a cornerstone of } \\
\text { American higher education. }\end{array}$ \\
\hline Business & $\begin{array}{l}\text { EDUCATION } \\
\text { IS BUSINESS }\end{array}$ & $\begin{array}{l}\text { I... outline some features of a new contract between higher } \\
\text { education and society. } \\
\text {....and what the product of an educational venture should be. } \\
\text {...the necessity for our educational system to begin dealing with the } \\
\text { problems of the times. } \\
\text { Educational institutions... are corporate entities... } \\
\text { Our faculty form spin-off companies... } \\
\text { Education is the best investment for the people... }\end{array}$ \\
\hline Journey & $\begin{array}{l}\text { EDUCATION } \\
\text { IS A } \\
\text { JOURNEY }\end{array}$ & $\begin{array}{l}\text { Teachers... guided them (students) on their journey along the rough } \\
\text { highway of society. } \\
\text { Education... is the ultimate pathway of success. }\end{array}$ \\
\hline Game & $\begin{array}{l}\text { EDUCATION } \\
\text { IS A GAME }\end{array}$ & $\begin{array}{l}\text { The National Institutes...became major players... } \\
\text {...stability is being played out in higher education. } \\
\text { Education plays a vital role in this modern world. }\end{array}$ \\
\hline $\begin{array}{l}\text { Building / } \\
\text { structure }\end{array}$ & $\begin{array}{l}\text { EDUCATION } \\
\text { IS A } \\
\text { BUILDING / } \\
\text { STRUCTURE }\end{array}$ & $\begin{array}{l}\text { Some jobs are jails. } \\
\text { Education is a construct that needs careful planning... }\end{array}$ \\
\hline $\begin{array}{l}\text { Wealth / } \\
\text { value }\end{array}$ & $\begin{array}{l}\text { EDUCATION } \\
\text { IS WEALTH / } \\
\text { VALUE }\end{array}$ & $\begin{array}{l}\text {...one should also learn to respect education... } \\
\text { Education ...is an essential commodity like food, clothing and } \\
\text { shelter. } \\
\text { Education is the real wealth for poor. }\end{array}$ \\
\hline
\end{tabular}


Stage 2. The analysis of the educational discourse (texts and TED Talks) allows us to conclude about the frequency and universality of the mechanism of metaphorization for scientific knowledge.

It is the metaphorical mechanism based on an intuitive search for analogy in an individual's existing experience that forms the basis of epistemology. The analysis of conceptual metaphors in the scientific educational discourse allows us to hypothesize that their epistemological function is more significant than expressive. Being a compact and at the same time information-intensive model of an integrating type, conceptual metaphor actively functions in the field of human scientific cognition.

Metaphorical conceptualization is involved in different levels of scientific activity: it is involved in terminological nomination, acts as a basic model in the formation of a science as a separate mental space, draws up abstract entities, their positioning, ways of operating them, thus shaping virtual area in which scientific activity and communication are carried out and participates in creating models for representing the object of the study and research results.

Conceptual metaphors in teaching English speech patterns may be used in three ways: firstly, as a means of training vocabulary skills; secondly, as a mnemonic means; thirdly, as a means of enhancing creative potential of students to produce their own scientific texts.

Each approach suggests a specific way of teaching actions.

Conceptual metaphor as a means of training vocabulary skills. Firstly, when dealing with educational discourse students are told what conceptual metaphors are, and how it is possible to generate plenty of ideas out of conceptual metaphors. The teacher can show the audience what it means for a concept to be metaphorically represented and how such a concept structures everyday language.

Students are better able to internalize the knowledge of metaphor-related units by having well-organized tasks such as production exercises and comprehension activities. The following activities can be included: gap-filling, matching, multiple choice, completion activities, metaphoric themes recognition, making sentences using metaphor, telling stories based on pictures, retelling and add-on stories, metaphor notebooks and flashcards, association of metaphor with mental images, hypothesizing and learning the origin of the metaphor, playing metaphor games, replacing marked expressions with metaphorical ones, real life questions, completing a story or a paragraph with metaphor-related units (Andreou \& Galantomos, 2008).

Cultivating students' metaphorical awareness teachers should make students know that metaphors are not only considered to be poetical or rhetorical units, but metaphors are a part of everyday speech that affects the ways we perceive, think, and act. Teachers should make the use of the teaching time in class to foster the 
ability of the students to analyze metaphors in educational discourse. Students should be encouraged to dig out the underlying essence of conceptual metaphor.

In addition, it is rather necessary for teachers to explain the relevant cultural background of metaphors to students: different living environments, geographical locations, world views and religious beliefs.

Conceptual metaphor as a mnemonic means. Conceptual metaphors may also serve the purpose of memorizing English speech patterns. The teaching algorithm includes: identifying conceptual metaphors in scientific texts, decomposing the basic conceptual metaphor into its functions where each function is accompanied with an example. For instance, a conceptual metaphor EDUCATION IS A LIVING BEING can be decomposed to the functions of serving, speaking, acting and suffering. The function of serving is presented by the example "Higher education has always served the needs of our communities". The information may be introduced in the form of a card as was created by the authors in the course of teaching Business English (Picture 1).

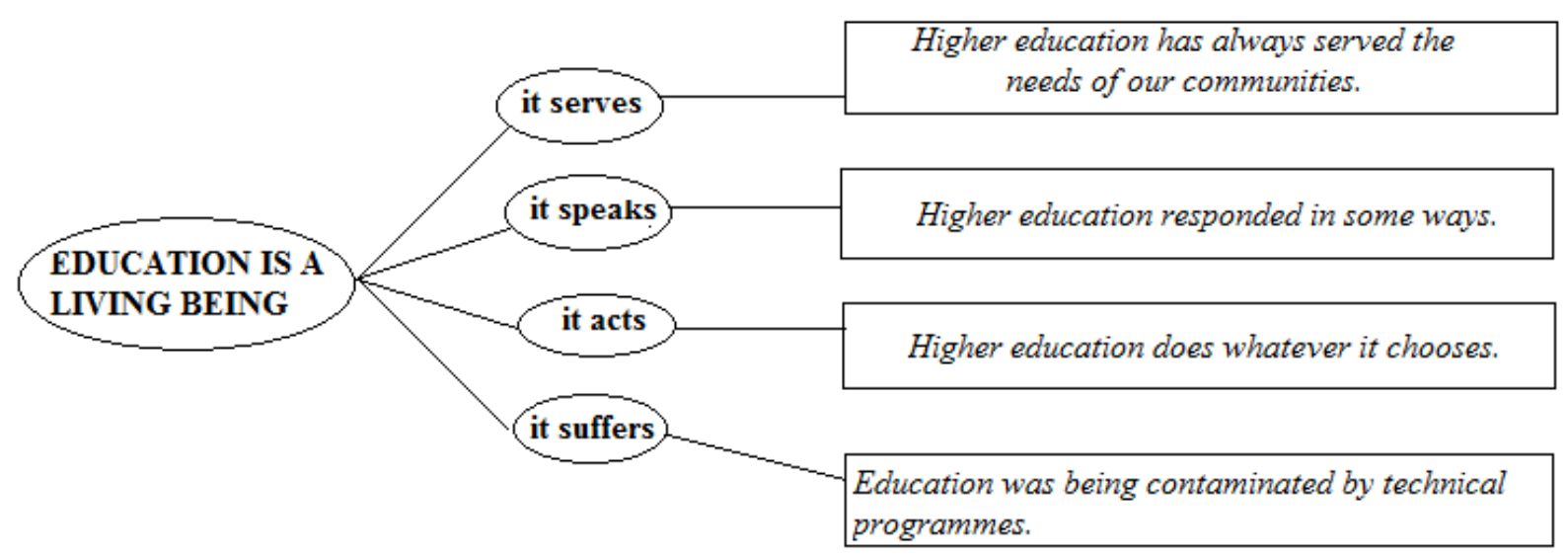

Figure 1 Mnemonic card EDUCATION IS A LIVING BEING

Conceptual metaphor as a means of enhancing creative potential of students to produce their own scientific texts. To produce individual scientific educational texts, penetrated with metaphors typical for foreign scientific educational discourse, in the form of presentations, reports, posters, abstracts and articles in English model based exercises for describing various concepts within a discourse can be proposed to graduates and postgraduates:

1) Describe the student as a builder using the verbs: construct, build, increase, add, expand, insert, strengthen the foundation. Use the nouns: stones, bricks, masonry, cornerstone, tier, level, window, door, basement, the upper floor, top. Think of the adjectives describing these nouns and adverbs characterizing the actions. 
2) Describe the activities of the teacher as a gardener in terms of gardening and agriculture using the verbs: sow, plant, grow, form, fertilize, reap. Use the nouns: crop, harvest, seed, fruit, tree, branch, root, stem. Think of the adjectives describing these nouns and adverbs characterizing the actions.

The model developed and tested by the authors can also be applied to other concepts mentioned above and their language representations that make up the academic discourse.

\section{Conclusions}

As a result, the main findings indicate that educational scientific discourse is dense with metaphoric units.

The most frequently conceptual metaphors used for EDUCATION may be considered as follows: a living being, a physical object, a business, a journey, a game, building / structure, wealth / value.

Traditionally, most students memorize vocabulary mechanically with unpleasant results. They do not realize metaphorical origin of most of the words, and metaphor is an important process of word meanings expanding and evolution. Metaphor serves as one of the important ways for language skills development.

While applying authentic written texts and TED Talks in teaching English speech patterns teachers should introduce the basic knowledge concerning the conceptual metaphor theory: how to recognize, understand and use metaphors. Finally, they should develop students' metaphorical competence, and encourage them to think, express, understand, improve students' creativity and imagination and cultivate their learning enthusiasm and interests.

The fact that metaphorical images, due to their mental nature are characterized by subjective diversity stimulates the variety of ways and styles of thinking about the modeled object and creates a stable aggregate idea of it. Thus, using conceptual metaphors can contribute to teaching postgraduates and graduate students in three ways: as a means of teaching vocabulary, as a mnemonic means and as a means of enhancing the production of author's scientific texts.

\section{References}

Altman, I. (1996). Higher Education and Psychology in the Millennium. American Psychologist, 51(4), 371-378.

Andreou, G., \& Galantomos, L. (2008). Teaching idioms in a foreign language context: preliminary comments on factors determining Greek idiom instruction. Metaphorik.de, 15, 7-26.

Broughton, G., Brumfit, C., Flavell, R., Hill, P., \& Pincas, A. (2003). Teaching English as a foreign language. New York: Routledge. 
Brown, B. (2010). The power of vulnerability. Retrieved from https://www.ted.com/talks/ brene_brown_the_power_of_vulnerability

Cameron, L., \& Deignan, A. (2006). The emergence of metaphor in discourse. Applied Linguistics, 27(4), 671-690.

De Botton, A. (2009). A kinder, gentler, philosophy of success. Retrieved from https://www.ted.com/talks/alain_de_botton_a_kinder_gentler_philosophy_of_success

De Grey, A. (2005). A roadmap to end aging. Retrieved from https://www.ted.com/talks/ aubrey_de_grey_a_roadmap_to_end_aging

Fisher, H. (2006). Why we love, why we cheat. Retrieved from https://www.ted.com/talks/ helen_fisher_why_we_love_why_we_cheat

Gibbs, R. (1994). The poetics of mind: Figurative thought, language and understanding. Cambridge: Cambridge University Press.

Gilbert, E. (2009). Your elusive creative genius. Retrieved from https://www.ted.com/talks/ elizabeth_gilbert_your_elusive_creative_genius

Hoffman, G. (2013). Robots with “soul”. Retrieved from https://www.ted.com/talks/ guy_hoffman_robots_with_soul

Kozhina, M.N. (1993). Stilistika russkogo jazyka. Moskva: Prosveshhenie.

Lakoff, G., \& Johnson, M. (1980). Metaphors We Live By. Chicago, IL: The University of Chicago Press.

Littlemore, J., Chen, P.T., Koester, A., \& Barnden, J. (2011). Difficulties in metaphor comprehension faced by international students whose first language is not English. Applied Linguistics, 32(4), 408-429.

Lodatko, E.A. (2013). Kognitivnye metafory i klasterizacija v pedagogicheskom modelirovanii. Vektor nauki TGU. Pedagogika i psihologija, 3, 146-150.

Pragglejaz Group. (2007). MIP: A Method for IdentifyingMetaphorically Used Words in Discourse. Metaphor and Symbol, 22(1), 1-39.

Robinson, K. (2006). Do schools kill creativity. Retrieved from https://www.ted.com/talks/ sir_ken_robinson_do_schools_kill_creativity

Schwartz, B. (2006). The paradox of choice. Retrieved from: https://www.ted.com/ talks/barry_schwartz_the_paradox_of_choice

Telija, V.N. (1988). Metaforizacija i ee rol' v sozdanii jazykovoj kartiny mira. Rol' chelovecheskogo faktora v jazyke: Jazyk i kartina mira. Moskva: Nauka, 173-205.

Vinogradov, V.V. (1997). Osnovnye tipy leksicheskih znachenij slova. Izbrannye trudy. Leksikologija i leksikografija. Moskva: Nauka, 162-189. 